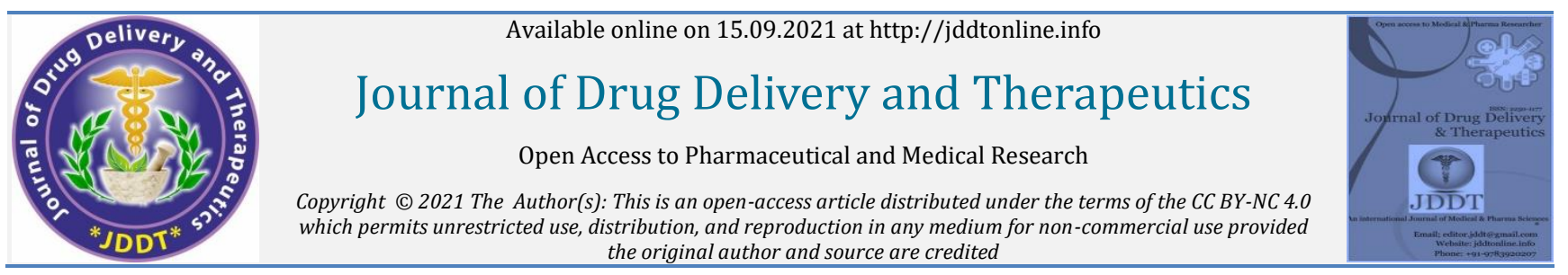

Open Access Full Text Article the original author and source are credited

Research Article

\title{
Capsule Formulation Essay of Herbal Extracts of Trunk Bark of Anogeissus leiocarpus (DC) Guill. Et Perr. (Combretaceae) for the Treatment of Hypertension
}

\author{
Ouedraogo Salfo ${ }^{1}$, Sombie C. Bavouma ${ }^{2}$, Diawara Zime Hermine ${ }^{2}$, Yameogo B.G. Josias ${ }^{2,3}$, Traore Tata

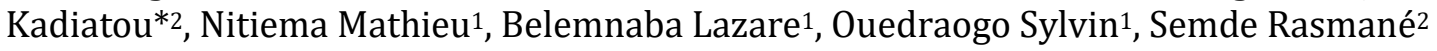 \\ 1. Département de médecine et pharmacopée traditionnelles-pharmacie (MEPHATRA-PH), Institut de recherche en science de la santé \\ (IRSS/CNRST), 03 BP 7047 Ouaga 03, Burkina Faso. \\ 2. Laboratoire du Développement du Médicament (LADME), Ecole doctorale de la santé, Université Joseph Ki-Zerbo, 03 BP 7021 Ouaga 03, \\ Burkina Faso. \\ 3. Laboratoire National de Santé Publique, Ministère de la santé, 09 BP 24 Ouagadougou 09, Burkina Faso.
}

\section{Article Info:}

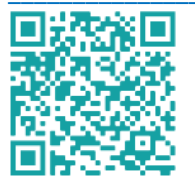

\section{Article History:}

Received 11 July 2021 Reviewed 01 August 2021

Accepted 06 Aug 2021

Published 15 Sep 2021

\section{Cite this article as:}

Ouedraogo S, Sombie CB, Diawara ZH, Yameogo BGJ, Traore TK, Nitiema M, Belemnaba Ouedraogo S, Semde R, Capsule Formulation Essay of Herbal Extracts of Trunk Bark of Anogeissus leiocarpus (DC) Guill. Et Perr. (Combretaceae) for the Treatment of Hypertension, Journal of Drug Delivery and Therapeutics. 2021; 11(5):90-95

DOI: http://dx.doi.org/10.22270/jddt.v11i5.4988

*Address for Correspondence:

Traore Tata Kadiatou, Laboratoire du Développement du Médicament (LADME), Ecole doctorale de la santé, Université Joseph Ki-Zerbo, 03 BP 7021 Ouaga 03, Burkina Faso.

\section{Abstract}

Introduction: The trunks barks of Anogeissus leiocarpus contains multiple antihypertensive components and are, therefore, widely used for the treatment of hypertension.

Objective: This study aimed to formulate capsules containing a freeze-dried aqueous extract of the trunk's barks.

Methodology: Three (03) capsule formulations were prepared using wet granulation from lyophilised aqueous extract of Anogeissus leiocarpus trunk bark, with different proportions of excipients including Corn starch used as the diluent, Polyvinylpyrrolidone K25 (PVP) used as binding agent and Magnesium stearate used as gliding agents. The filling of capsules was done using a semi-automatic capsule filler with empty capsules of size 3 . The flow properties of the granules and the quality control were performed according to the European Pharmacopoeia 10th ed.

Results/Discussion: All granules had good flow properties, and the F1 and F3 formulations had the best pharmaceutics characteristics according to the recommendations of the European Pharmacopoeia 10th ed. The mean levels of phenolic tracers were $0.039 \pm 0.0097$ mg gallic acid equivalent per capsule (GAE/capsule) for the $F 1$ formulation and $0.059 \pm 0.0063 \mathrm{mg} \mathrm{GAE} /$ capsule for the F3 formulation.

Conclusion: This study allowed the galenic formulation of capsules based on extracts of good characteristic quality for the treatment of hypertension.

Keywords: Anogeissus leiocarpus, extract, excipients, formulations, capsule

\section{INTRODUCTION}

The African continent is at a crossroads as it faces an unprecedented epidemic of cardiovascular disease. Indeed, there are millions of hypertensives in Africa, and the proportion of people affected is expected to increase by $2025 .{ }^{1}$

The burden of cardiovascular disease is overgrowing in Africa, that it has become a public health problem throughout the African Region. ${ }^{2}$

Given increasing prevalence of hypertension and the complexity of this disease, modern therapy offers a wide range of antihypertensive drugs. ${ }^{3}$ There are emergency forms, usually administered in injectable form, and ambulatory forms. Unfortunately, the costs of these drugs are often beyond the reach of Third World populations. ${ }^{3}$ This leads a large population segment to treat themselves with plant and animal-based medicines transmitted from generation to generation. 4,5 In recent years, there has been an increase in research on antihypertensive medicinal plants used by traditional practitioners that show some effectiveness. ${ }^{6}$ Among these plants, we note Anogeissus leiocarpus which has been the subject of numerous studies (ethnobotanical, phytochemical, pharmacological, toxicological). 7,8,9,10,11,12 Despite these studies, no adapted galenic form that would facilitate its use is available. The literature indicates that herbal medicines range from simple forms, herbal teas, capsules containing plant powders, to more elaborate arrangements forms in which a purified plant extract or a pure molecule isolated from a plant enters as the "active" of the medicine, then designated as a phyto-drug. ${ }^{13}$ The present aimed to develop a pharmaceutical grade capsule formulation from the freeze-dried aqueous extracts of the trunk bark of Anogeissus leiocarpus. 


\section{MATERIALS AND METHODS}

\section{Materials}

\section{Plant's materials}

Fresh trunks barks of Anogeissus leiocarpus (Combretacaea) were harvested at Loumbila commune (Burkina Faso) and identified by a botanist from the ecology laboratory of the University of Joseph KI-ZERBO in reference to the herbarium $\mathrm{N}^{\circ} 1544$. The barks have been dried and crushed to powder.

\section{Excipients and packaging materials}

The galenic form studied here was a dry oral formulation with conventional release. The active ingredient was some lyophilised aqueous extracts of Anogeissus leiocarpus trunks bark powders. Different types of excipients and packaging materials have been used. Corn starches (Batch 03406) were provided by CERESTAR GL, Germany. Magnesium stearate (Batch 14.153.874), Polyvinylpyrrolidone K30 (Batch 14G04B05-298548) were purchased from FAGRON (Belgium). Empty capsules (Batch 51532812) were provided by CAPSUGEL, (Belgium). Food bag (Batch 03550100) was obtained from BUERKLE GMBH, (Germany). Ethanol was obtained from CAMEG (Burkina Faso). Distilled water was prepared in the galenic laboratory (IRSS).

\section{Methods}

\section{Preparation of extracts and preliminary phytochemical} caractérization of the extract

Hundred (100) grams of vegetable powder have been boiled with $1 \mathrm{~L}$ sterile distilled water while 30 minutes. The extracts obtained were frozen for 24 hours and then lyophilized at 96 hours. These extracts were analysed using different methods, such as macroscopic examination of botanical

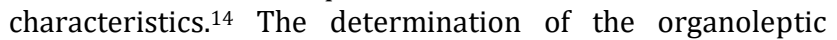
characteristics consisted of powders observation (touching, smelling and tasting). The residual moisture content of the extracts were determined using the thermogravimetric method. ${ }^{15,16}$ One (01) $\mathrm{g}$ is weighed in triplicate and placed in a previously tared watch glass in an infrared moisture Analyser (MF-50, US).

\section{Chemical screening with TLC}

Phytochemical screening was performed on chromatoplates (60 F254, $20 \times 20 \mathrm{~cm}$ glass support, Fluka -Silica gel) following methods described in the literature.17,18 The main chemical groups were searched by thin layer chromatography (TLC) such as steroidal compounds, terpene compounds, phenolic compounds and alkaloidal compounds. The dry sample was solubilised in its extraction solvent at the concentration of $10 \mathrm{mg} / \mathrm{mL}$ (10 $\mathrm{mg}$ in $1 \mathrm{~mL}$ of solvent) and $5 \mu \mathrm{L}$ were deposited on the TLC plate for chromatogram development.

\section{Determination of phenolic compounds by UV- spectrophotometric method}

The amount of total phenolics in the drug retained from the plant was estimated by the Singleton method, using the Folin-Ciocalteu reagent (FCR). ${ }^{19}$ FCR is a mixture of phosphotungstic acid and phosphomolybdic acid, which is reduced during the oxidation of phenols in alkaline medium to a mixture of blue oxides of tungsten and molybdenum. The latter show an absorption maximum at the wavelength of $760 \mathrm{~nm}$, with an intensity proportional to the quantity of polyphenols present in the sample.

The reaction mixture consisted of $25 \mu \mathrm{L}$ of the $0.1 \mathrm{mg} / \mathrm{mL}$ sample, $105 \mu \mathrm{L}$ of $0.2 \mathrm{~N}$ FCR which was left to incubate for five minutes in the dark. To this mixture was added $100 \mu \mathrm{L}$ of a sodium carbonate solution ( $75 \mathrm{~g} / \mathrm{L}$ in distilled water). The mixture was then left to incubate for one (1) hour in the dark and then the absorbance was measured at $760 \mathrm{~nm}$ wavelength in a spectrophotometer against a gallic acid standard curve.

The tests were performed four times, and the results expressed as grams of gallic acid equivalent per $100 \mathrm{~g}$ of dry sample (mg EAT/100 g).

The total phenolic content of the extract was obtained by the formula:

$$
\mathbf{T}=\frac{c \times D}{C i} \times 100
$$

$\mathrm{T}=$ Content in mg Gallic Acid Equivalent in $100 \mathrm{~g}$ extract

$\mathrm{C}=$ sample concentration read $(\mu \mathrm{g} \mathrm{EAT} / \mathrm{mL})$ on the standard curve

$\mathrm{D}=$ Dilution factor of the sample under assay

$\mathrm{Ci}=$ initial concentration of the sample solution to be determined

\section{Preparation of granules}

The granules were prepared by the wet granulation method. It was carried out using a GLA-ORY FREWITT type granulator. The mass to be granulated was weighed, mixed and wetted with ethanol until a crumbly paste was obtained. The extract was mixed with corn starch and Polyvinylpyrrolidone K25 (PVP) as binding agents are added till it produces coherent mass a then required quantity of magnesium stearate using ethanol as wetting liquid was added. The set was passed through an oscillating granulator with a 1.25 mesh sieve. Granules obtained were gently spread and dried in a MEMMERT oven at a temperature of 45 ${ }^{\circ} \mathrm{C}$ for 12 hours. Dry granules were weighed and their weight was recorded. The dried granules were mixed with magnesium stearate were added in required quantities.

Table 1: The composition of granules (amounts of the substances are given in parts)

\begin{tabular}{llll}
\hline Formule/ gram & F1 & F2 & F3 \\
\hline Polyvinylpyrrolidone K25 (PVP) & 0 & 0.28 & 0.12 \\
\hline Magnesium stearate & 0.12 & 0.12 & 0.12 \\
\hline Extract & qs & qs & qs \\
\hline Corn starch & 11.12 & 10.9 & 11
\end{tabular}

$Q s^{*}:$ Sufficient quantity to make 


\section{Evaluation of granules}

The macroscopic and organoleptic characteristics and the residual moisture content were carried out according to the methods mentioned above.

Prepared granules were subjected for determination of bulk density, tapped density, Hausner's ratio, Carr's index, angle of repose and bulkiness to assess granule's the flow property. ${ }^{20,21}$

\section{Fabrication and quality control of capsules}

Prepared granules were packed into hard gelatin capsule (size 3) using semi-automatic capsule filler machine.

\section{Determination of uniformity of weight}

This test was performed according to European Pharmacopoeia 2.9.5.22 Twenty (20) capsules were randomly selected and individually weighed using a precision balance (Sartorius, France). The full capsules were individually weighed and then carefully emptied of their contents with a swab. The empty capsules were then individually weighed to determine the difference between the contents of the capsules. The average mass (M), mass deviations, in percent $[100(\mathrm{mi}-\mathrm{M}) / \mathrm{M}]$ from the average mass and coefficient of variation (CV) were calculated. These deviations were compared to the tolerated limits specified in the pharmacopoeia. ${ }^{22}$

\section{Disintegration time of capsules}

This test involved 6 capsules taken at random and introduced individually into the tubes of a disintegrating device. A disc was placed on each capsule, and the disintegrating medium used was distilled water maintained at $37^{\circ} \mathrm{C}$. The time of complete disintegration of the first capsule and that of the last one was noted. ${ }^{22}$

\section{Determination of total phenolics as a tracer}

The amount of total phenolics in the plant extracts was estimated by the Singleton method using the Folin-Ciocalteu reagent (FCR). ${ }^{19}$ The reaction mixture consisted of $25 \mu \mathrm{L}$ of extract at $0.1 \mathrm{mg} / \mathrm{mL}, 105 \mu \mathrm{L}$ of $0.2 \mathrm{~N} \mathrm{RCF}$, which was incubated for $5 \mathrm{~min}$ in the dark. To this mixture was added $100 \mu \mathrm{L}$ of a sodium carbonate solution $(75 \mathrm{~g} / \mathrm{L}$ in distilled water). It was incubated for $01 \mathrm{~h}$ in the dark, and then the absorbance was measured at the wavelength of $760 \mathrm{~nm}$ with a spectrophotometer against a gallic acid standard curve. The tests were carried out four times on each sample, and the results are expressed in micrograms of gallic acid equivalent per milligram of dry extract $(\mu \mathrm{g}$ GAE / mg extract).

\section{Uniformity of total phenolic content of capsules}

A sample of 10 capsules was taken at random. Each capsule was weighed and emptied of its contents and macerated individually in water for $10 \mathrm{~min}$ by magnetic agitation in a beaker containing $50 \mathrm{ml}$ of distilled water at $25^{\circ} \mathrm{C}$. The determination was carried out according to method described by Singleton et al. ${ }^{19}$ and interpretation according to the European Pharmacopoeia 10th edition 2.9.6.22

\section{RESULTS AND DISCUSSION}

\section{Preliminary phytochemical analysis of extract}

The freeze-dried extract of Anogeissus leiocarpus (Combretacaea) was brown (Figure 1) with astringent odor and slightly bitter flavor. The extraction yield was $26.77 \pm$ 2.86, and the residual moisture content (THR) was $4.43 \pm 0.49 \%$.

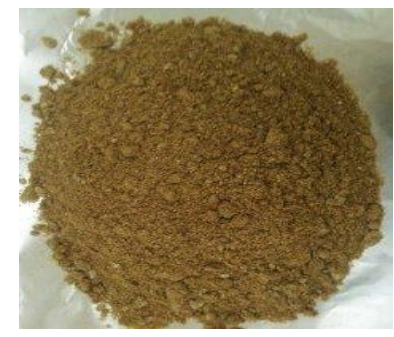

Figure 1: Freeze-dried extract of Anogeissus leiocarpus

The chromatographic analysis revealed the presence of several chemical groups represented by figure 2 . This figure could be used as a chromatographic fingerprint. The blue fluorescence after spraying with NEU reagent characterises the presence of phenolic compounds in the extracts. These compounds could be used as tracers for the quality control of the extract and finished products. Indeed, chromatographic techniques allow a quantitative and qualitative analysis. To facilitate the quality control of raw materials and plant-based medicines, the European Medicines Agency (EMA) proposes an approach based on the determination of the chemical fingerprint of these phytomedicines and the monitoring of chemical tracers. ${ }^{23,24}$

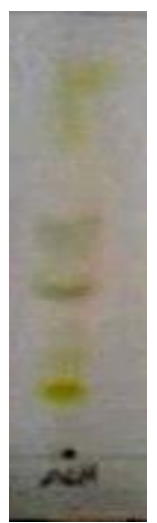

A

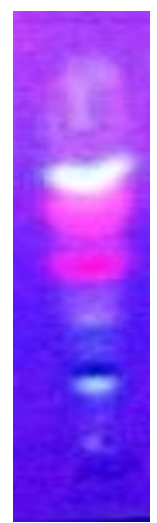

B
Figure 2: TLC of the hexane fractions of the freeze-dried extracts after daylight (A) and UV observation at $254 \mathrm{~nm}$ (B).

The determination of phenolic compounds chosen as tracer to give a value of $1.71899 \pm 0.0426 \mu \mathrm{g} \mathrm{EAG} / \mathrm{mg}$ extract. The calibration curve of the gallic acid (Figure 3) obtained has the equation: $\mathrm{y}=29.07 \mathrm{x}+0.020\left(\mathrm{R}^{2}=0.999\right)$. This curve was used for the determination of gallic acid in the samples.

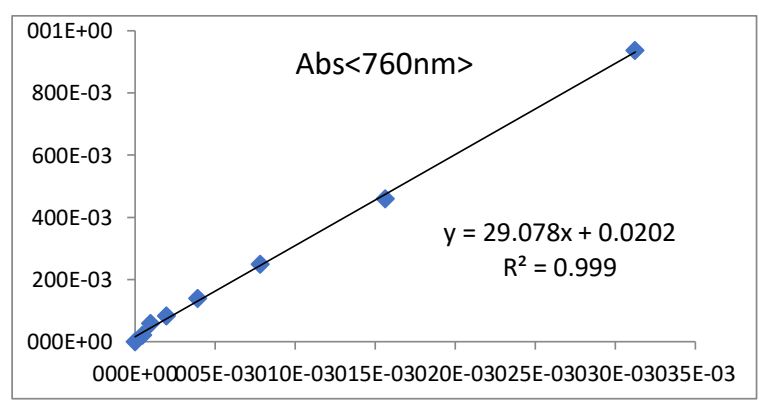

Figure 3: Standard line obtained with gallic acid

\section{Preparation and evaluation of granules}

The pellets were prepared from the extract using various excipients at different concentrations by the wet granulation method. The pellets were brown (Figure 4) with an astringent odor and slightly bitter flavor. This indicates retention of the extract characteristics. The residual moisture content (RMC) was $6.21 \pm 0.32 \%$. 


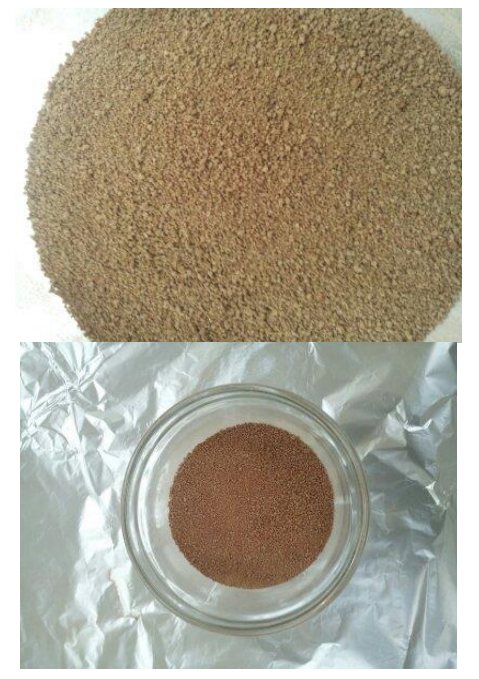

Figure 4: Pictures Anogeissus leiocarpus granules
The prepared granules were subjected to preformulation studies; the results are presented in Table I.

Granules were prepared from extract using various excipients containing different concentration by wet granulation method and prepared granules were subjected to preformulation studies. The results of which is shown in Table I.

There was no significant difference in the bulk densities and packing densities of the prepared pellets. The Hausner ratio was between 1.11 and 1.14. Since the Hausner ratios were less than 1.24, this indicates a good flow property of the granules. The granules of almost all formulations gave a compressibility index between 10.10 and $12.50 \%$ and an angle of repose between 23.7 and 27.1‥ A compressibility index greater than $20 \%$ is considered an indication of poor flowability, and less than $15 \%$ is considered an indication of excellent granule flowability. Since all the formulations had a Carr's index of less than $15 \%$ and an angle of repose of less than $30^{\circ}$, the granules have good flow properties.

Table I: Pharmacotechnical characteristics of granules

\begin{tabular}{lllllll}
\hline $\begin{array}{l}\text { Desig- } \\
\text { nations }\end{array}$ & $\begin{array}{l}\text { Bulk density } \\
(\mathbf{g} / \mathbf{m l})\end{array}$ & $\begin{array}{l}\text { Tapped density } \\
\mathbf{( g / m l )}\end{array}$ & $\begin{array}{l}\text { Hausner } \\
\text { ratio }\end{array}$ & $\begin{array}{l}\text { Carr's index } \\
\mathbf{( \% )}\end{array}$ & $\begin{array}{l}\text { Angle of repose } \\
\left(\emptyset^{\circ}\right)\end{array}$ & Bulkiness \\
\hline F1 & $0.84 \pm 0.02$ & $0.96 \pm 0.05$ & $1.14 \pm 0.01$ & $12.50 \pm 0.05$ & $27.1 \pm 0.03$ & $1.37 \pm 0.04$ \\
\hline F2 & $0.89 \pm 0.01$ & $0.99 \pm 0.01$ & $1.11 \pm 0.04$ & $10.10 \pm 0.03$ & $23.7 \pm 0.05$ & $1.43 \pm 0.02$ \\
\hline F3 & $0.81 \pm 0.03$ & $0.91 \pm 0.03$ & $1.12 \pm 0.02$ & $10.99 \pm 0.02$ & $24.4 \pm 0.07$ & $1.32 \pm 0.05$ \\
\hline
\end{tabular}

\section{Formulation and evaluation of capsules}

All capsule formulations were subjected to various evaluations, and the results are shown in Table 2.

The capsules manufactured were ivory in color and size 3 . (Figure 5).

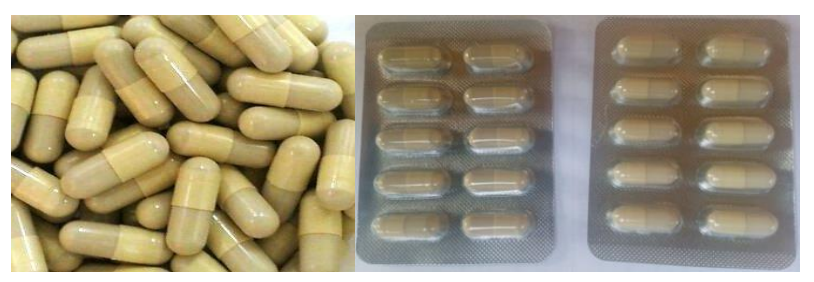

Figure 5: Pictures of capsules containing Anogeissus leiocarpus granules

Concerning mass variation, the capsules complied with the standards accepted by the 10th edition of the European Pharmacopoeia, which stipulates that the mass of the capsules may vary up to $10 \%$ for capsules of less than 300 $\mathrm{mg}$ and $7.5 \%$ for weights above $300 \mathrm{mg} .{ }^{22}$ The capsules analysed had mean masses of $123.5 \pm 0.004 \mathrm{mg}$ to $128.4 \pm 0.0053 \mathrm{mg}$, with coefficients of variation ranging from 2.17 to 3.64 (Table II). Thus, none of the analysed capsules containing powder mixtures exceeded the acceptable range.

This test of uniformity of mass of the capsules conforming with the pharmacopoeia standards presumes that the quantity of active extract by capsule would be thus homogeneous and would make it possible to avoid any variability of the administered dose. As for the disintegration time, the formulations without binding agent disintegrated faster than the others. This finding confirmed a correlation between capsule qualities and the physicochemical properties of the excipients. However, the F2 formulation had the highest disintegration time. It was above the standards accepted by the 10th edition of the European Pharmacopoeia, stipulating that this value should be less than 15 minutes.

The disintegration test of the capsules showed an acceptable disintegration for the capsules of formulations F1 and F3 according to the 10th edition of the European Pharmacopoeia. The capsules disintegrated in 11 minutes for F1, 15 minutes for F2 and 13 minutes for F3. Formulations F1 and F3 were then used for further studies concerning the uniformity of tracer content (phenolic compounds).

Table II: Mass uniformity and disintegration time

\begin{tabular}{lll}
\hline Designations & $\begin{array}{l}\text { Weight } \\
\text { variation } \\
\text { (mg) }\end{array}$ & $\begin{array}{l}\text { Disintegration } \\
\text { Test (mins) }\end{array}$ \\
\hline F1 & $123,5 \pm 0,004$ & $11.18 \pm 0.8$ \\
\hline F2 & $128,4 \pm 0,0053$ & $15.36, \pm 0.3$ \\
\hline F3 & $127 \pm 0,0045$ & $13.21 \pm 0.7$ \\
\hline
\end{tabular}

The uniformity of phenolic compounds content retained as the tracer is represented in Tables III and IV. The phenolic compound content of 10 capsules randomly taken from each formulation was $0.039 \pm 0.0097 \mathrm{mg} \mathrm{GSE} /$ capsule for $\mathrm{F} 1$ and $0.059 \pm 0.0063$ for F3. From these results, both formulations are within the standards of the European Pharmacopoeia $10 \mathrm{ed}$. The latter states that the preparation passes the test if the individual content of up to one unit is outside the limits of 85 per cent to 115 per cent of the mean content and if it is not outside the boundaries of 75 per cent to 125 per cent of the mean content 22 . 
Table III: Phenolic compound content of F1 capsules

\begin{tabular}{lllll}
\hline Designation / F1 & $\begin{array}{l}\text { Mass (mg) of content } \\
\text { per capsule }\end{array}$ & $\begin{array}{l}\text { Content in mg of } \\
\text { GSE/capsule }\end{array}$ & $\begin{array}{l}\text { Percentage (\%) of EAG } \\
\text { content/capsule }\end{array}$ & $\begin{array}{l}\text { Percentage content (\%) of } \\
\text { average content }\end{array}$ \\
\hline 1 & 120.8 & $0.036 \pm 0.0018$ & 0.029 & 92.27 \\
\hline 2 & 119.8 & $0.04 \pm 0.0037$ & 0.033 & 103.39 \\
\hline 3 & 119.4 & $0.039 \pm 0.004$ & 0.033 & 100.45 \\
\hline 4 & 123.9 & $0.038 \pm 0.0064$ & 0.031 & 98.54 \\
\hline 5 & 125.2 & $0.041 \pm 0.0011$ & 0.033 & 105.32 \\
\hline 6 & 123 & $0.039 \pm 0.0068$ & 0.031 & 99.67 \\
\hline 7 & 120.6 & $0.039 \pm 0.0075$ & 0.032 & 99.72 \\
\hline 8 & 118.6 & $0.038 \pm 0.0077$ & 0.032 & 100.14 \\
\hline 9 & 120.7 & $0.039 \pm 0.0024$ & 0.032 & 103.06 \\
\hline 10 & 124.5 & $0.040 \pm 0.0015$ & 0.032 & \\
\hline Average & 121.65 & $0.039 \pm 0.0097$ & 0.032 & 0.001 \\
\hline Standard deviation & 2.31 & 0.0014 & & \\
\hline
\end{tabular}

Table IV: Phenolic compound content of F3 capsules

\begin{tabular}{lllll}
\hline Designation / F3 & $\begin{array}{l}\text { Mass (mg) of content per Content in mg of } \\
\text { capsule }\end{array}$ & $\begin{array}{l}\text { Percentage (\%) of EAG } \\
\text { content/capsule }\end{array}$ & $\begin{array}{l}\text { Percentage content (\%) } \\
\text { of average content }\end{array}$ \\
\hline 1 & 131.9 & $0.050 \pm 0.0014$ & 0.038 & 84.08 \\
\hline 3 & 128 & $0.058 \pm 0.0072$ & 0.045 & 98.47 \\
\hline 4 & 133.1 & $0.064 \pm 0.0099$ & 0.048 & 108.9 \\
\hline 5 & 128.1 & $0.056 \pm 0.0034$ & 0.043 & 103.1 \\
\hline 6 & 125.8 & $0.061 \pm 0.0050$ & 0.048 & 103.3 \\
\hline 7 & 132.9 & $0.061 \pm 0.0063$ & 0.046 & 103.6 \\
\hline 8 & 127.7 & $0.061 \pm 0.0080$ & 0.048 & 102.4 \\
\hline 9 & 127.7 & $0.061 \pm 0.0008$ & 0.047 & 97.7 \\
\hline 10 & 131.3 & $0.058 \pm 0.0026$ & 0.044 & 103.6 \\
\hline Average & 131 & $0.061 \pm 0.0083$ & 0.047 & 0.045 \\
\hline Standard deviation & 129.75 & $0.059 \pm 0.0063$ & 0.0032 & \\
\hline
\end{tabular}

\section{CONCLUSIONS}

This study produced capsule formulations based on freezedried aqueous extract of Anogeissus leiocarpus for the treatment of hypertension. These formulations were made through the addition of excipients. The use of wet granulation of the mixtures in the form of granules followed by a filling of the capsule made it possible to obtain a galenic form meeting the recommendations of the pharmaceutical standards. The pharmaceutics characteristics follow the European Pharmacopoeia 10th ed specifications for the F1 and F3 formulations. These forms could serve as alternatives for the administration of the extracts of trunks barks of the plant. They could also improve the quality of treatment and compliance through ease of administration and storage. Further stability studies should be considered.

\section{CONFLICT OF INTEREST}

The author has no conflict of interest.

\section{ACKNOWLEDGEMENT}

The authors thank the FONRID (National Research and Innovation Fund for Development) for their technical and financial support, as well as the traditional health practitioners for their collaboration. 


\section{REFERENCES}

1. Addo, J.; Smeeth, L.; Leon, D. A., Hypertension in sub-saharan Africa: a systematic review. Hypertension (Dallas, Tex. : 1979) 2007; 50(6):1012-8. https://doi.org/10.1161/HYPERTENSIONAHA.107.093336

2. Comité.régional.de.l'Afrique Les maladies cardiovasculaires dans la région africaine: situation actuelle et perspectives: rapport du Directeur régional; OMS. Bureau régional de l'Afrique: 2005.

3. Blacher, J.; Baes, M.; Marchal, A.; Younes, W.; Legedz, L.; Safar, M., Nouvelles stratégies thérapeutiques dans l'hypertension artérielle: Quelles recommandations et comment les appliquer? La Presse Médicale 2005; 34(18):1279-1285. https://doi.org/10.1016/S0755-4982(05)84174-0

4. OMS Promotion du rôle de la médecine traditionnelle dans les systèmes de santé: stratégie de la Région africane AFR/RC50/9; Bureau régional de l'Afrique, : Harare : , 2001.

5. WHO Stratégie de l'OMS pour la médecine traditionnelle pour 2002-2005; Genève: Organisation mondiale de la Santé: 2002.

6. Diallo, D.; Guissou, I. P.; Haidara, M.; Kasilo, O. M.; Tall, C., Recherche sur la médecine traditionnelle africaine: hypertension. African Health Monitor 2010.

7. Belemnaba, L.; Nitiema, M.; Traoré, S.; Somé, N.; Traore, A.; Ouédraogo, S.; Guissou, I., Recherche de plantes à potentialités antihypertensives dans la biodiversité du Burkina Faso. Pharmacopée et médecine traditionnelle africaine 2014; 17(1).

8. Ahmad, I.; Wudil, A., Phytochemical screening and toxicological studies of aqueous stem bark extract of Anogeissus leiocarpus in rats. Asian Journal of Scientific Research 2013; 6 (4):781. https://doi.org/10.3923/ajsr.2013.781.788

9. Ouédraogo, S.; Belemnaba, L.; Traoré, A.; Bucher, B.; Guissou, I., Etude de la toxicité et des propriétés pharmacologiques de l'extrait aqueux de Anogeissus leiocarpus (DC) Guill. et Perr (Combretaceae). Pharmacopée et médecine traditionnelle africaine 2011; 15.

10. Belemnaba, L.; Ouédraogo, S.; Auger, C.; Chataigneau, T.; Traore, A.; Guissou, I.; Lugnier, C.; Schini-Kerth, V. B.; Bucher, B., Endothelium-independent and endothelium-dependent vasorelaxation by a dichloromethane fraction from Anogeissus Leiocarpus (DC) Guill. Et Perr.(Combretaceae): possible involvement of cyclic nucleotide phosphodiesterase inhibition. African Journal of Traditional, Complementary and Alternative Medicines 2013; 10(2):173-179.

https://doi.org/10.4314/ajtcam.v10i2.1

11. Ouédraogo, S.; Sombié, B. C.; Ouédraogo, J. C. W.; Nitiéma, M.; Belemnaba, L.; Ouédraogo, S.; Semdé, R., Quality control of trunk's barks of Lannea microcarpa Engl. and K. Krause and Anogeissus leiocarpus (DC) Guill. \& Perr. for the manufacture of phytomedicines for the treatment of hypertension. International Journal of Phytopharmacy 2017; 7(4):36-41.

12. Ouédraogo, S.; Sombié, B. C.; Ouédraogo, J. C. W.; Traoré, T. K.; Traoré, S.; Nitiéma, M.; Lazare, B.; Sylvin, O.; Rasmané, S.; Pierre, G. I., Standardization of Extracts from Trunks's Barks of Lannea microcarpa engl. and K. Krause (Anacardiaceae) and Anogeissus leiocarpus (DC) Guill. and Perr.(Combretaceae) for the Formulation of Antihypertensive Herbal Medicines.". Int. J. Pharm. Sci. Rev. Res 2018; 48(1):92-97.

13. Kasilo, O. M. J.; Wambebe, C.; Nikiema, J. B.; Nabyonga-Orem, J., Towards universal health coverage: advancing the development and use of traditional medicines in Africa. 2019, 4 (Suppl 9), e001517, p.11. https://doi.org/10.1136/bmjgh-2019-001517

14. Bauer, R., Franz, G., Modern European Monographs for Quality Control of Chinese Herbs. Planta Med 2010; 76:2004-2011. https://doi.org/10.1055/s-0030-1250532

15. Ph.Eur., European Directorate for the Quality of Medicines and HealthCare (EDQM) of the Council of Europe. European Pharmacopoeia. General chapter Characters section in monographs 6th Edition tome 1 Strasbourg,France. 1218p. 2008.

16. Ph.Eur., European Pharmacopoeia : Technical Guide for the elaboration of monographs. European Directorate for the Quality of Medicines \& HealthCare 2011, 6th Edition 72.

17. Mamyrbékova-Békro, J. A.; Konan, K. M.; Békro, Y.-A.; Gobin, M.; Bi, D.; Bi, T.; Mambo, V.; Boua Boua, B., Phytocompounds of the extracts of four medicinal plants of Côte D'ivoire and assessment of their potential antioxidant by thin layer chromatography. Eur. J. Scient. Res 2008; 24:219-228.

18. Chaaib Kouri, F. Investigation phytochimique d'une brosse à dents africaine "Zanthoxylum zanthoxyloides" (Lam.) Zepernick et Timler (Syn. "Fagara zanthoxiloides" L.) (Rutaceae). Université de Lausanne, 2004.

19. Singleton, V. L.; Orthofer, R.; Lamuela-Raventos, R. M., Analysis of total phenols and other oxidation substrates and antioxidants by means of Folin-Ciocalteu reagent. Methods in enzymology 1999; 299:152-178. https://doi.org/10.1016/S0076-6879(99)990171

20. Ranpura, V. D.; Kathiriya, A.; Shah, K. V., Formulation, development and characterization of sustained release bilayered tablet of Valsartan and Pioglitazone $\mathrm{HCl}$ Pharma Science Monitor 2013; 4(3).

21. Mahajan, P.; Mahajan, S.; Mishra, D., Valsartan release from sustained release matrix tablet and effect of cellulose derivatives. Int J Pharm Sci 2011; 2:521-30.

22. Ph.Eur., Pharmacopée Européenne 10ème édition. 2019; p 1-379.

23. Li, Y.; Wu, T.; Zhu, J.; Wan, L.; Yu, Q.; Li, X.; Cheng, Z.; Guo, C., Combinative method using HPLC fingerprint and quantitative analyses for quality consistency evaluation of an herbal medicinal preparation produced by different manufacturers. Journal of pharmaceutical and biomedical analysis 2010; 52(4):597-602. https://doi.org/10.1016/j.jpba.2010.01.018

24. He, Y.; Zhao, H. D.; Tang, L. Y.; Wang, Z. J.; Zhang, Q. W., Quantititive study for chromatographic fingerprints of processed products of Paeonia lactiflora. Zhongguo Zhong yao za zhi $=$ Zhongguo zhongyao zazhi $=$ China journal of Chinese materia medica 2007; 32(12):1161-4. 